\title{
Genetic Diversity of the Indian Populations of 'Candidatus Liberibacter asiaticus' Based on the Tandem Repeat Variability in a Genomic Locus
}

\author{
Dilip Kumar Ghosh, Sumit Bhose, Manali Motghare, Ashish Warghane, Krishanu Mukherjee, Dipak Kumar Ghosh Sr., \\ Ashwani Kumar Sharma, Milind Shivratan Ladaniya, and Siddarame Gowda
}

First, second, third, fourth, and eighth authors: National Research Centre for Citrus, PB 464, P.O. Shankarnagar, Nagpur 440010, India; fifth author: The Whitney Laboratory for Marine Bioscience, University of Florida, 9505 Ocean Shore Blvd., St. Augustine 32080; sixth author: Directorate of Research, Bidhan Chandra Krishi Viswavidyalaya, Kalyani, West Bengal, India; seventh author: Department of Biotechnology, Indian Institute of Technology, Roorkee 247 667, India; and ninth author: University of Florida, Citrus Research and Education Center, 700 Experiment Station Road, Lake Alfred 33850.

Accepted for publication 3 March 2015.

\begin{abstract}
Ghosh, D. K., Bhose, S., Motghare, M., Warghane, A., Mukherjee, K., Ghosh, D. K., Sr., Sharma, A. K., Ladaniya, M. S., and Gowda, S. 2015. Genetic diversity of the Indian populations of 'Candidatus liberibacter asiaticus' based on the tandem repeat variability in a genomic locus. Phytopathology 105:1043-1049.

Citrus huanglongbing (HLB, citrus greening disease) is an extremely destructive disease affecting citrus and causes severe economic loss to the crop yield worldwide. The disease is caused by a phloem-limited, noncultured, gram-negative bacteria Candidatus Liberibacter spp., the widely present and most destructive species being 'Candidatus Liberibacter asiaticus'. Although the disease has been reported from almost all citrus growing regions of India, knowledge on the molecular variability of the pathogen ' $\mathrm{Ca}$. L. asiaticus' populations from different geographical regions and cultivars is limited. In the present study, variability of the Indian ' $\mathrm{Ca}$. L.

asiaticus' based on the tandem repeats at the genomic locus CLIBASIA_01645 was characterized and categorized into four classes based on the tandem repeat number (TRN); Class I (TRN $\leq 5$ ), Class II (TRN $>5 \leq 10)$, Class III $($ TRN $>10 \leq 15)$, and Class IV (TRN $>15)$. The study revealed that the Indian population of ' $\mathrm{Ca}$. L. asiaticus' is more diverse than reported for Florida and Guangdong populations, which showed less diversity. While Florida and Guangdong populations were dominated by a TRN5 and TRN7 genotype, respectively, the Indian ' $\mathrm{Ca}$. L. asiaticus' populations with TRN copy numbers $9,10,11,12$, and 13 were widely distributed throughout the country. Additionally, TRN2 and TRN17 genotypes were also observed among the Indian ' $\mathrm{Ca}$. L. asiaticus' populations. The predominant ' $\mathrm{Ca}$. $\mathrm{L}$. asiaticus' genotypes from the northeastern region of India were TRN6 and TRN7 (53.12\%) and surprisingly similar to neighboring South China populations. Preliminary results showed absence of preference of citrus cultivars to any specific ' $\mathrm{Ca}$. L. asiaticus' genotype.
\end{abstract}

Citrus, a native to China, has been growing in India since 2500 BC (1,4,27). Among all diseases affecting citrus crop globally, huanglongbing (HLB) is considered the most destructive disease. Estimates have suggested that over 60 million citrus trees have been destroyed worldwide by this disease alone $(3,18)$. The disease was first noted in China in the late 1800s (24) and was confirmed in India in 1967 when a successful transmission of the disease with the Asian citrus psyllid was achieved $(4,5,12,36)$. HLB has also been reported in São Paulo in Brazil and Florida, Texas, and California in the United States $(17,18)$. It is of great concern to the worldwide citrus industry $(8,17,32)$. The disease affects all commercial citrus cultivars including preferred root stocks.

HLB is associated with the Candidatus Liberibacter spp., a phloemlimited, gram-negative, as yet not cultured alpha-proteobacterium. Based on geographic location of their origin, temperature tolerance and sequence variations in $16 \mathrm{~S}$ rRNA region, they are classified into three species: 'Ca. L. asiaticus', 'Ca. L. africanus', and ' $C a$. L. americanus' $(3,22)$. The pathogen is transmitted by psyllid vectors, but differs in their vector species specificity and the environment. ' $C a$. L. asiaticus' and ' $C a$. L. americanus' are heat-tolerant and

Corresponding author: D. K. Ghosh; E-mail address: ghoshdk@hotmail.com

*The $\boldsymbol{e}$-Xtra logo stands for "electronic extra" and indicates that one supplementary figure and two supplementary tables are published online.

http://dx.doi.org/10.1094/PHYTO-09-14-0253-R

(C) 2015 The American Phytopathological Society vectored by Diaphorina citri Kuwayama, while ' $\mathrm{Ca}$ L. africanus' is heat-sensitive and vectored by Trioza erytreae Del Guercio $(3,5)$. In the Indian subcontinent, ' $\mathrm{Ca}$. L. asiaticus' is the most prevalent species.

Methods for distinguishing ' $\mathrm{Ca}$. L. asiaticus' isolates are important for understanding the genetic structure of pathogen populations and their ecological and epidemiological studies. Initially, conserved genomic loci such as $16 \mathrm{~S}$ rDNA sequences were used to analyze the populations of ' $\mathrm{Ca}$. L. asiaticus' (22). Subsequently, the loci of $16 \mathrm{~S}$ rRNA gene, $\beta$-operon in ribosomal protein genes ( $r p l A J)$, and an outer membrane protein gene $(\mathrm{omp})$ in ' $\mathrm{Ca}$. L. asiaticus' were compared $(2,9,10)$. However, sequence analysis revealed very limited variations in these genes $(9,10,30)$. In general, the extent of genetic variations at these loci (16S rDNA, rplAJ gene, and omp gene) was low, rendering it difficult to characterize bacterial populations of different origins with adequate resolution. However, recent studies have focused on more variable loci as complete ' $\mathrm{Ca}$. L. asiaticus' genome sequence become available (12). Tomimura et al. (33) analyzed the single nucleotide polymorphisms (SNPs) in a bacteriophage-type DNA polymerase gene and revealed three clusters of ' $\mathrm{Ca}$. L. asiaticus' strains from Southeast Asia. Focusing on the ' $\mathrm{Ca}$. L. asiaticus' populations in China, Liu et al. (25) analyzed the variation of a prophage gene and found that the gene frequencies were significantly different between bacterial populations from Guangdong and Yunnan provinces. A unique genomic region of ' $\mathrm{Ca}$. L. asiaticus' showing locus mosaicism was recently characterized that revealed that ' $\mathrm{Ca}$. L. asiaticus' isolates in China 
could be divided into high and low altitude groups (35). Similarly, the availability of complete genome sequence $(1.23 \mathrm{Mb})$ of the pathogenic ' $C a$. L. asiaticus' strain psy62 (12) allowed diversity analysis of the bacterial populations based on tandem repeat numbers (TRN) of few genomic loci. Simple sequence repeat markers, also known as microsatellites, are tandem repetitive DNA sequences with repeat motif lengths of 2 bp or more (34). In general, the variability of the repeats are believed to be caused by slippedstrand mispairing (31), the genetic instability of polynucleotide tracts, especially poly (G-T) (19), and DNA recombination between homologous repeat sequences (34). Simple sequence repeat with a potential variable number of tandem repeats in bacterial DNA have been used as markers for differentiating and subtyping strains of several bacterial species including Xylella fastidiosa (7), which causes variegated chlorosis of citrus and Pierce's disease in grapevines $(23,26)$. Islam et al. (20) developed microsatellite markers and identified three major genetic groups of ' $\mathrm{Ca}$. L. asiaticus' worldwide. Chen et al. (6) studied the variation analysis of TRN at a genomic locus (CLIBASIA_01645) of ' $C a$. L. asiaticus' strains in Guangdong, China and Florida and observed that the Florida bacterial population was dominated by a TRN $=5$ genotype $(84.5 \%)$, while the Guangdong bacterial population predominantly contained a TRN = 7 genotype, albeit at $47.6 \%$. Katoh et al. (23) identified four tandem repeat loci showing high sensitivity in detection of ' $\mathrm{Ca}$. L. asiaticus' diversity among isolates from Japan, Taiwan, and Indonesia. Locus CLIBASIA_01645 (designated as 005) was one of them with highest overall Nei's diversity value (23). Recently, Deng et al. (11) made double-locus analyses and evaluated genomic variations of ' $\mathrm{Ca}$. L. asiaticus' populations based on the analyses of two genomic loci: trn1, characteristic of variable TRNs and snp1, characteristic of SNPs.

HLB, known by different names in different countries, was familiar as citrus dieback in India since the eighteenth century and was attributed to several factors including soil disorders, nutritional deficiencies, involvement of fungi and viruses (4). In view of the serious nature of the citrus dieback problem and its economic importance to Indian citriculture, the Indian Government in the year 1965 invited Lilian Fraser, an Australian scientist to investigate the possible cause of citrus dieback in the country. After visiting the major citrus growing regions of India, she concluded that the dieback affecting citrus trees in India carry the identical symptoms of HLB seen in South Africa (13). However, the experimental proof of the presence of HLB in India came in 1967 when the successful transmission of HLB agent was obtained by the insect vector, citrus psylla (Diaphorina citri) (5). Subsequently, several reports confirm the wide-spread distribution of HLB and its insect vector in all citrus growing states of India including Maharashtra, Andhra Pradesh, Punjab, Tamil Nadu, West Bengal (Darjeeling Hills), and Bihar as well as the northeastern states of Assam, Sikkim, and Mizoram etc., which are geographically closer to countries like China, Nepal, and Bhutan $(1,15,27)$. However, very limited biological and genomic data are available on the diversity of the bacterial populations among the different geographical origins of India. In light of the success in differentiating ' $\mathrm{Ca}$. L. asiaticus' populations at locus CLIBASIA_01645 (6), the present study was directed to determine genetic diversity among the populations of ' $\mathrm{Ca}$. L. asiaticus' infecting various citrus cultivars in different geographical locations of India based on the tandem repeat (AGACACA) number variability in the same genomic locus.

\section{MATERIALS AND METHODS}

Sample collection and culture maintenance. Surveys were conducted between the years 2010 and 2013 to record the incidence and distribution of HLB in different geographical regions of India (Fig. 1). We collected potential HLB symptomatic twigs, leaves, and bud sticks from different citrus cultivars from 12 states (Table 1; Fig. 1). Representative samples were used for biological indexing by graft inoculation on Mosambi sweet orange (Citrus sinensis) indicator plants and were maintained in an insect-proof greenhouse at temperatures of $30^{\circ} \mathrm{C}$ during the day and $25^{\circ} \mathrm{C}$ at night.

DNA extraction and ' $\boldsymbol{C a}$. $\mathrm{L}$. asiaticus' detection. The collected symptomatic samples were washed, wiped with $70 \%$ ethanol to avoid any surface contamination, and blot dried. Midribs and petioles were excised and ground in liquid nitrogen, and $100 \mathrm{mg}$ of the powdered sample was used for DNA extraction using the DNeasy Plant mini kit (Qiagen, Hilden, Germany) according to the manufacturer's protocol. 'Ca. L. asiaticus' in these samples was identified using previously described polymerase chain reaction (PCR) amplification of 16S rDNA primer set OI1/OI2c $(14,21)$.

PCR amplification for bacterial population analysis. The PCR amplification targeting CLIBASIA_01645 locus was carried out using primers LapGP-1f (5' GACATTTCAACGGTATCGAC $\left.3^{\prime}\right)$ and LapGP-1r (5' GCGACATAATCTCACTCCTT 3') (6). The reaction was carried out in a $25 \mu$ reaction volume containing $100 \mathrm{ng}$ of total DNA, $1 \times$ PCR buffer, $1.5 \mathrm{mM} \mathrm{MgCl}_{2}, 0.2 \mathrm{mM}$ of dNTP each, $0.4 \mathrm{mM}$ of each primer, $1.25 \mathrm{U}$ of GoTaq flexi DNA polymerase (Promega) and nuclease-free water. The My Cycler thermal cycler (Bio-Rad, Hercules, CA) was programmed for one cycle of 4 min at $95^{\circ} \mathrm{C}$ followed by 35 cycles of $30 \mathrm{~s}$ at $95^{\circ} \mathrm{C}, 45 \mathrm{~s}$ at $58^{\circ} \mathrm{C}, 60 \mathrm{~s}$ at $72^{\circ} \mathrm{C}$, and a final extension at $72^{\circ} \mathrm{C}$ for $10 \mathrm{~min}$. The amplified DNA was visualized in a UV GelDoc system (Bio-Rad) after electrophoresis with ethidium bromide at a constant voltage of $100 \mathrm{~V}$ for $90 \mathrm{~min}$ in a $1.5 \%$ agarose in $1 \times$ TAE buffer

Nucleotide sequencing and data analysis. Amplified PCR products were excised and eluted from the gel using the GenElute Gel Extraction Kit (Sigma-Aldrich, St. Louis, MO) and sequenced (Chromous Biotech Pvt. Ltd., Bangalore, India) using the ABI BigDye v 3.1 terminator cycle sequencing protocols (Applied BioSystems, Foster City, CA). Fluorescent labeled extension products were analyzed by the dye terminator method on an ABI 3500xL DNA sequencer (Applied Bio-systems). Sequence similarity searches were conducted using the BLAST algorithm of the National Center for Biotechnology Information (NCBI) and visual FASTA result tool of the European Molecular Biology Laboratory, European Bioinformatics Institute (EMBL-EBI). Tandem repeats (AGACACA) present in the CLIBASIA_01645 genomic locus were counted and compared manually. Similarly, the frequencies of different TRNs among genotypes were calculated and bacterial population differences were statistically analyzed by an F test (16).

\section{RESULTS}

Disease incidence, symptoms, transmission, and culture maintenance. Out of 151 samples collected from different states representing different geographical regions (Fig. 1), a total of 81 samples were positive for HLB with OI1/OI2c set of primers. Among them, 38 were mandarins (Citrus reticulata), 19 were sweet orange (Citrus sinensis), 12 were acid lime (Citrus aurantifolia), three were pomelo (Citrus grandis), two of each were sour orange (Citrus aurantium), Assam lemon (Citrus limon) and Rangpur lime (Citrus limonia), and one each were of Cadena Fina (Citrus sinensis 'Cadenera'), Dancy tangerine (Citrus tangerine), and grape fruit (Citrus paradisi) (Table 1). A comparison of the disease incidence among different states of India showed that $47 \%$ of the samples from northern Maharashtra, 62\% from eastern Maharashtra (Vidarbha region), 30\% from Madhya Pradesh, 71\% from Uttar Pradesh, 50\% from Uttarakhand, $73 \%$ from Tamil Nadu, 26\% from Andhra Pradesh, 41\% from Karnataka, 70\% from West Bengal, $80 \%$ from Sikkim, $37 \%$ from Mizoram, and $72 \%$ of the samples from Assam were found infected. During the present survey, all samples collected from Manipur were diagnosed as negative for HLB. However, more extensive sampling needs to be carried out to ascertain this observation. Predominant symptoms of HLB included prominent yellowing of leaf veins in mandarin, leaf yellowing with green islands and leaf mottling in sweet orange, chlorotic leaves and yellow mottling in acid lime, pomelo, and grapefruit, and general yellowing 
of leaf in Rangpur lime and Assam lemon. Upon graft inoculation, the disease was successfully transferred to indicator plants with characteristic HLB symptoms within 3 to 6 months postinoculation. All HLB-affected seedlings were maintained in an insect-proof greenhouse for further study.

Analysis of the CLIBASIA_01645 locus. Samples that were PCR-positive with the primer set OI1/OI2c also showed positive amplification with the primer set LapGP-1f/LapGP-1r and generated an approximate amplicon of $650 \mathrm{bp}$ (Fig. 2A) with single PCR amplicon group (SAG). However, in some cases, variations in the amplicon size potentially reflecting the TRN variation were observed (Fig. 2B). All these amplified products were sequenced from both orientations and sequence details have been deposited in the GenBank database under accession nos. KJ885187 to KJ885255 and KJ921625 to KJ921636. Homology searches using the BLAST tool at the NCBI database revealed significant sequence similarities with the CLIBASIA_01645 locus of ' $C a$. L. asiaticus' strain psy62. Sequence analysis showed tandem repeats of AGACACA found in all amplicon sequences (Table 1); however, TRNs varied among the isolates. In Maharashtra state, especially in Vidarbha region, ' $\mathrm{Ca}$. L. asiaticus' strains with TRNs of 9 (TRN9) were predominant (Table 1) with a frequency of $35 \%$. Except for one isolate from Assam, Maharashtra was the only state in which the TRN9 strain was observed (Table 1). In the northeastern states of India, especially in Assam, the bacterial strain with TRNs of 7 (TRN7) was predominant with a frequency of $40.6 \%$. The strain with the highest TRNs (TRN17) was reported in the sweet orange cultivar Mosambi from the northern Maharashtra region (Supplementary Tables S1 and S2).

As the TRNs among isolates from most of the geographical regions were variable, we classified the genotypic variation based on the number of TRNs. We categorized the strains into four classes; Class I of TRNs $\leq 5$, Class II of TRNs $>5$ but $\leq 10$, Class III of TRNs $>$ 10 but $\leq 15$, and Class IV of TRNs $>15$. We observed that the Class II genotype was most predominant $(54.32 \%)$ followed by the Class I genotype $(30.86 \%)$, and the least predominant was Class IV genotype $(2.46 \%)$. Maharashtra state, particularly the northern Maharashtra region, was the only state with Class IV genotype (Fig. 1, Table 1). 'Ca. L. asiaticus' populations from the eastern

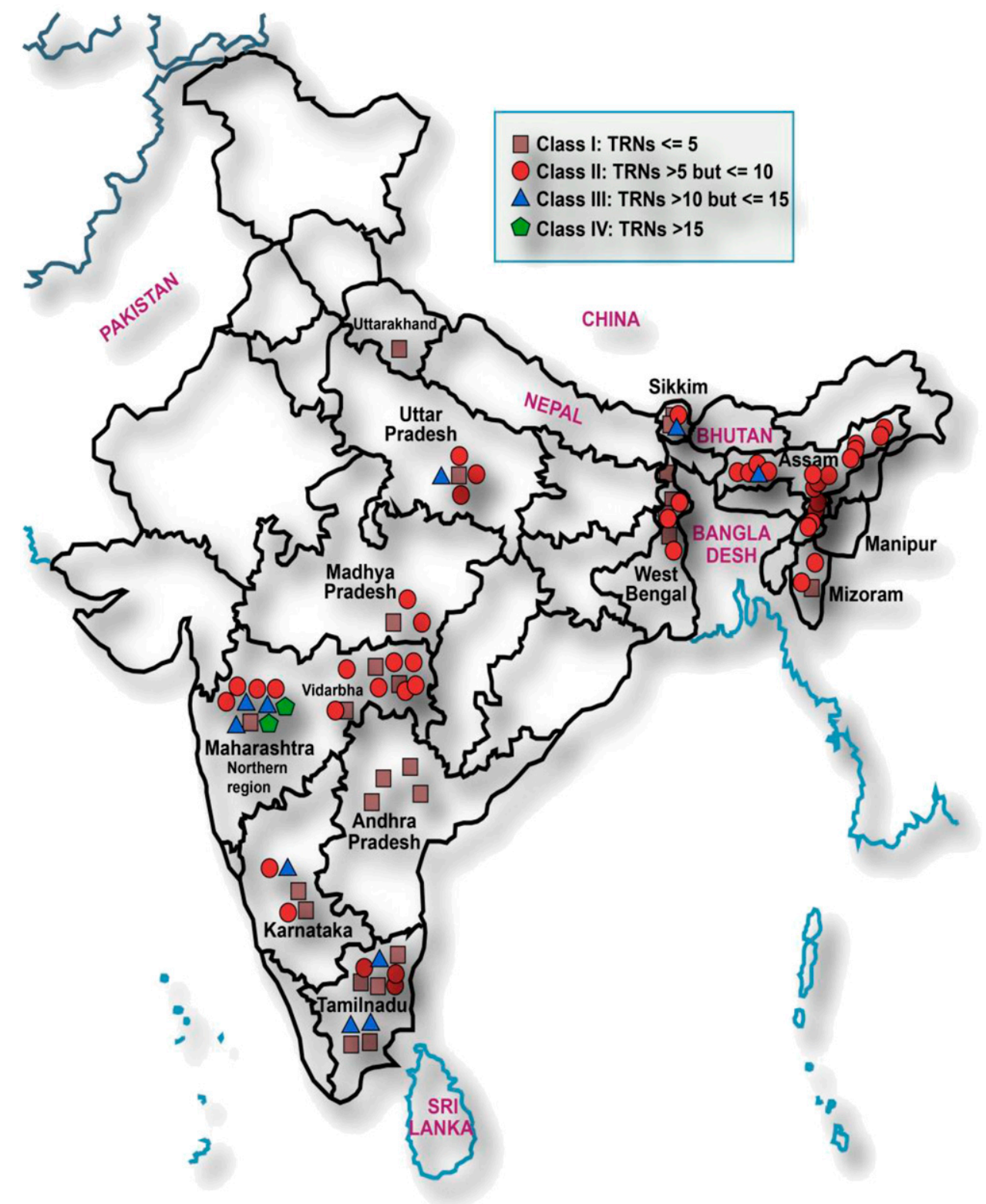

Fig. 1. Map of India showing the distributions of Indian 'Candidatus Liberibacter asiaticus' isolates collected from different citrus growing regions of India. The classification is based on the varying tandem repeat numbers (TRNs) present at the CLIBASIA_01645 genomic locus. All Indian 'Ca. L. asiaticus' isolates are classified under four classes (classes I to IV, refer to the main manuscript for further details) and shown on the map with the help of different shapes. The name of the states from where samples were collected are mentioned on the map and other states are left blank for clarity. 
state of West Bengal and the northeastern states of Sikkim and Mizoram were of Class II (71.8\%), and in Assam nearly 95\% of the bacterial populations were of Class II (Supplementary Fig. S1). In northern Maharashtra, Uttar Pradesh, Tamil Nadu, Karnataka, Sikkim, and Assam, Class III genotype was observed with an overall frequency of $12.34 \%$, while Andhra Pradesh and Uttarakhand predominately had Class I genotype (Fig. 3). The results of test of significance with an $\mathrm{F}$ test showed significant differences $(P=0.05)$ for the distribution of frequencies of TRNs in ' $\mathrm{Ca}$. L. asiaticus' isolates between the states.

In an effort to study association of citrus cultivars with specific classes of the pathogen, DNA was isolated from different citrus cultivars infected with ' $C a$. L. asiaticus' and the CLIBASIA_01645 locus was analyzed. Among mandarin, Class II genotype was more predominant with a $68.42 \%$ frequency, followed by Class I and Class III with frequencies of 28.94 and $2.63 \%$, respectively (Fig. 4). The sweet orange predominately contained Class II genotype with $52.63 \%$. However, sweet orange was the only group that also contained Class IV genotype. In contrast, acid limes and Rangpur lime predominately contained Class I and Class III genotype, respectively, and the remaining cultivars contained varying amounts of Class I and Class II genotype (Fig. 4). The analysis of variance test ( $\mathrm{F}$ test) among the distribution of TRNs within different citrus cultivars was observed as nonsignificant (at $P=0.05$ ).

\section{DISCUSSION}

India, with diverse environmental conditions in different states, would potentially support increased pathogen diversity in the country. Knowledge of the genetic diversity of ' $\mathrm{Ca}$. L. asiaticus' from different geographical regions and citrus cultivars is required for predicting the disease risk. Although HLB has been reported in India to infect all commercial cultivars for many years, the study of genomic variations among the ' $\mathrm{Ca}$. L. asiaticus' bacterial population has not been available. The primer set LapGP-1f/LapGP-1r for CLIBASIA_01645 locus has been used successfully to characterize ' $\mathrm{Ca}$. L. asiaticus' populations from China and the United States $(6,26)$. Chen et al. (6) observed single PCR amplicon group (SAG), whereas Ma et al. (26) observed both SAG and multiple PCR amplicon group (MAG) using the same set of primers, i.e., LapGP-1f/LapGP-1r for CLIBASIA_01645 locus. We used a similar approach to characterize the CLIBASIA_01645 locus to study the bacterial populations from different citrus growing regions in India and observed presence of SAG (Fig. 2) as observed with 'Ca. L. asiaticus' populations from China and the United States (6).

DNA sequences with tandem repeats are known to be highly dynamic in both prokaryote and eukaryote genomes. Based on the TRN copy number variation, Chen et al. (6) classified the Florida and Guangdong bacterial populations into two strain groups: TRN

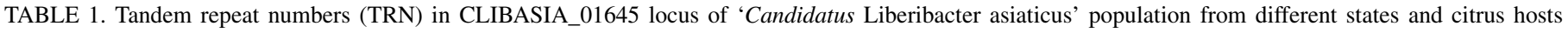
grown in India ${ }^{a}$

\begin{tabular}{|c|c|c|c|c|c|c|c|}
\hline \multirow[b]{2}{*}{ Sample } & \multirow[b]{2}{*}{ State/region } & \multicolumn{2}{|c|}{ Host } & \multirow[b]{2}{*}{ Isolate code } & \multirow[b]{2}{*}{ Accession no. } & \multirow[b]{2}{*}{ TRN } & \multirow[b]{2}{*}{ Classification } \\
\hline & & Cultivar & Botanical name & & & & \\
\hline 1 & Northern Maharashtra, Western India & Nagpur mandarin & Citrus reticulata & 'MH-R-CM' & KJ885230 & 8 & Class II \\
\hline 2 & Northern Maharashtra, Western India & Mosambi, sweet orange & Citrus sinensis & 'MH-R-MO' & KJ885231 & 9 & Class II \\
\hline 3 & Northern Maharashtra, Western India & Rangpur lime & Citrus limonia & 'MH-R-RL' & KJ885232 & 12 & Class III \\
\hline 4 & Northern Maharashtra, Western India & Acid lime & Citrus aurantifolia & 'MH-R-AL' & KJ885233 & 9 & Class II \\
\hline 5 & Northern Maharashtra, Western India & Mosambi, sweet orange & Citrus sinensis & 'MH-BL3P4' & KJ885234 & 7 & Class II \\
\hline 6 & Northern Maharashtra, Western India & Mosambi, sweet orange & Citrus sinensis & 'MH-BL3P7' & KJ885235 & 13 & Class III \\
\hline 7 & Northern Maharashtra, Western India & Mosambi, sweet orange & Citrus sinensis & 'MH-BL3P21' & KJ885236 & 17 & Class IV \\
\hline 8 & Northern Maharashtra, Western India & Mosambi, sweet orange & Citrus sinensis & 'MH-BL3P25' & KJ885237 & 2 & Class I \\
\hline 9 & Northern Maharashtra, Western India & Mosambi, sweet orange & Citrus sinensis & 'MH-BL4P11' & KJ885238 & 12 & Class III \\
\hline 10 & Northern Maharashtra, Western India & Mosambi, sweet orange & Citrus sinensis & 'MH-BL5P5' & KJ885239 & 16 & Class IV \\
\hline 11 & Vidarbha-Maharashtra, Central India & Nagpur mandarin & Citrus reticulata & 'IPB-24' & KJ885209 & 9 & Class II \\
\hline 12 & Vidarbha-Maharashtra, Central India & Nagpur mandarin & Citrus reticulata & 'IPB-49' & KJ885210 & 9 & Class II \\
\hline 13 & Vidarbha-Maharashtra, Central India & Nagpur mandarin & Citrus reticulata & 'IPB-66’ & KJ885211 & 9 & Class II \\
\hline 14 & Vidarbha-Maharashtra, Central India & Nagpur mandarin & Citrus reticulata & 'IPB-118' & KJ885212 & 5 & Class I \\
\hline 15 & Vidarbha-Maharashtra, Central India & Nagpur mandarin & Citrus reticulata & 'IPB-127' & KJ885213 & 8 & Class II \\
\hline 16 & Vidarbha-Maharashtra, Central India & Nagpur mandarin & Citrus reticulata & 'B35-7' & KJ885214 & 9 & Class II \\
\hline 17 & Vidarbha-Maharashtra, Central India & Nagpur mandarin & Citrus reticulata & 'B35-10' & KJ885215 & 5 & Class I \\
\hline 18 & Vidarbha-Maharashtra, Central India & Nagpur mandarin & Citrus reticulata & 'B35-13' & KJ885216 & 8 & Class II \\
\hline 19 & Vidarbha-Maharashtra, Central India & Nagpur mandarin & Citrus reticulata & 'B35-51' & KJ885217 & 5 & Class I \\
\hline 20 & Vidarbha-Maharashtra, Central India & Nagpur mandarin & Citrus reticulata & 'B35-120' & KJ885218 & 9 & Class II \\
\hline 21 & Madhya Pradesh, Central India & Nagpur mandarin & Citrus reticulata & 'R4P9' & KJ885224 & 5 & Class I \\
\hline 22 & Madhya Pradesh, Central India & Nagpur mandarin & Citrus reticulata & 'Ex-1' & KJ885225 & 6 & Class II \\
\hline 23 & Madhya Pradesh, Central India & Nagpur mandarin & Citrus reticulata & 'Ex-2' & KJ885226 & 6 & Class II \\
\hline 24 & Uttar Pradesh, North India & Mosambi, sweet orange & Citrus sinensis & 'A-3' & KJ921632 & 6 & Class II \\
\hline 25 & Uttar Pradesh, North India & Mosambi, sweet orange & Citrus sinensis & 'An' & KJ921633 & 13 & Class III \\
\hline 26 & Uttar Pradesh, North India & Mosambi, sweet orange & Citrus sinensis & 'AN-3' & KJ921634 & 6 & Class II \\
\hline 27 & Uttar Pradesh, North India & Mosambi, sweet orange & Citrus sinensis & 'AN-4' & KJ921635 & 6 & Class II \\
\hline 28 & Uttar Pradesh, North India & Mosambi, sweet orange & Citrus sinensis & 'AN-5' & KJ921636 & 5 & Class I \\
\hline 29 & Uttarakhand, North India & Pummelo & Citrus grandis & 'P-3' & KJ885255 & 4 & Class I \\
\hline 30 & Tamil Nadu, South India & Mangudi acid lime & Citrus aurantifolia & 'TNmal-2' & KJ885244 & 5 & Class I \\
\hline 31 & Tamil Nadu, South India & Acid lime & Citrus aurantifolia & 'TNal-3' & KJ885245 & 13 & Class III \\
\hline 32 & Tamil Nadu, South India & Acid lime & Citrus aurantifolia & 'TNal-4' & KJ885246 & 4 & Class I \\
\hline 33 & Tamil Nadu, South India & Acid lime & Citrus aurantifolia & 'TNal-5' & KJ885247 & 11 & Class III \\
\hline 34 & Tamil Nadu, South India & Acid lime & Citrus aurantifolia & 'TNal-6' & KJ885248 & 10 & Class II \\
\hline 35 & Tamil Nadu, South India & Acid lime & Citrus aurantifolia & 'TNal-7' & KJ885249 & 5 & Class I \\
\hline 36 & Tamil Nadu, South India & Acid lime & Citrus aurantifolia & 'TNal-8' & KJ885250 & 5 & Class I \\
\hline 37 & Tamil Nadu, South India & Acid lime & Citrus aurantifolia & 'TNal-9' & KJ885251 & 8 & Class II \\
\hline 38 & Tamil Nadu, South India & Acid lime & Citrus aurantifolia & 'TNal-10' & KJ885252 & 7 & Class II \\
\hline 39 & Tamil Nadu, South India & Acid lime & Citrus aurantifolia & 'TNal-11' & KJ885253 & 5 & Class I \\
\hline 40 & Tamil Nadu, South India & Acid lime & Citrus aurantifolia & 'TNal-12' & KJ885254 & 13 & Class III \\
\hline
\end{tabular}

a Class I (TRN $\leq 5)$, Class II (TRN $>5 \leq 10)$, Class III (TRN $>10 \leq 15)$, and Class IV (TRN $>15)$. 
copy less than $10($ TRN < 10) or more than $10($ TRN > 10), but we observed that this scheme was inadequate to accommodate much diversity seen with Indian ' $C a$. L. asiaticus' strains. In ' $C a$. L. asiaticus' populations from Florida, TRN5 was the predominate genotype with a frequency of $84.4 \%$, followed by TRN4 with much smaller frequency of $4.5 \%$, whereas in ' $\mathrm{Ca}$. L. asiaticus' populations of Guangdong, TRN7 was the most frequent (47.6\%), followed by TRN6 with a frequency of $29.2 \%$ (6) and TRN 9, 10, 11, and 12 were not observed or nonexistent (6). On the contrary, Indian ' $C a$. L. asiaticus' populations with TRN numbers 9, 10, 11, 12, and 13 (a total of $24.4 \%$ ) were widely represented. ' $\mathrm{Ca}$. L. asiaticus' populations with TRN2 and TRN17 were also observed but were not recorded in ' $\mathrm{Ca}$. L. asiaticus' populations of China and the United States (6). Therefore, to accommodate a more diverse TRN pattern/genotype in a simplified manner, we arbitrarily classified the Indian ' $\mathrm{Ca}$. L. asiaticus' populations as Class I to IV.

The Maharashtra state has the greatest acreage of citrus cultivation and is a large producer of citrus in India. This state also has a long history of citrus cultivation and sweet orange is a widely grown citrus cultivar. Our results reflect that the ' $\mathrm{Ca}$. L. asiaticus' strains collected from Maharashtra state belonged to all four classes, suggesting higher variability compared with other citrus growing states. Class II of ' $\mathrm{Ca}$. L. asiaticus' was observed in all states except Andhra Pradesh, which potentially suggests selection pressure (unknown biotic- or abiotic-factors) for genotypes as was earlier reported by Chen et al. (6) for Florida and Guangdong populations of ' $C a$. L. asiaticus'.
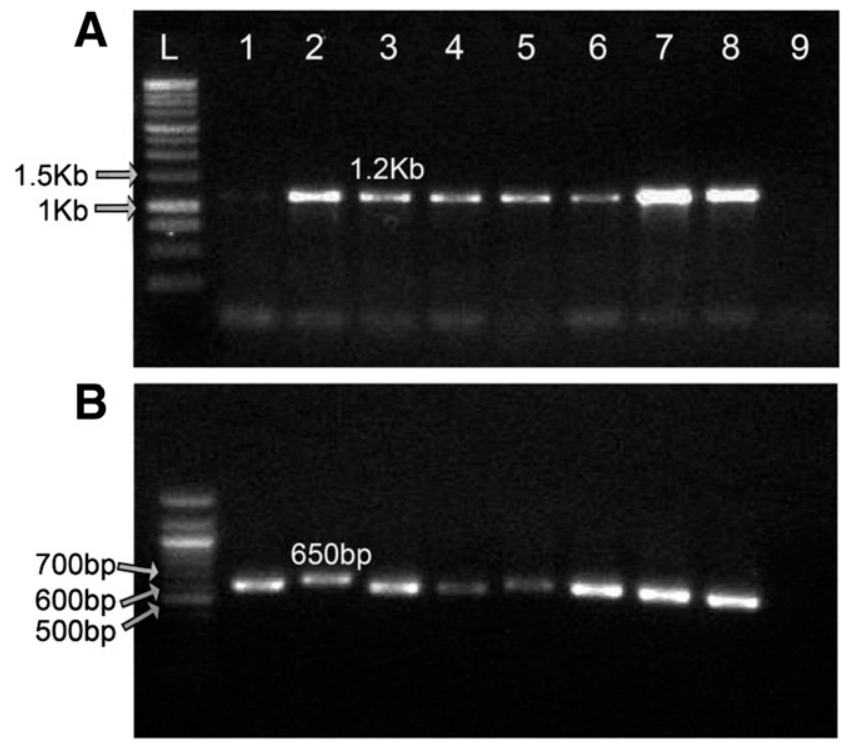

Fig. 2. Gel picture showing the polymerase chain reaction bands, which were amplified using the primers set OI1/OI2c. A, Primer pair LapGP-1f/LapGP-1r was used and obtained a fragment size of $1.2 \mathrm{~kb}$ shown in Lanes 1 to 8 . Lane number 9 was used as a negative control. In lane L, 1-kb size marker was used. $\mathbf{B}$, Variation in fragment size is visible owing to the variation of tandem repeat copy numbers at the CLIBASIA_01645 locus. In lane L, the size marker of $100 \mathrm{bp}$ was used.

\begin{tabular}{|c|c|c|c|c|c|c|c|}
\hline \multirow[b]{2}{*}{ Sample } & \multirow[b]{2}{*}{ State/region } & \multicolumn{2}{|c|}{ Host } & \multirow[b]{2}{*}{ Isolate code } & \multirow[b]{2}{*}{ Accession no. } & \multirow[b]{2}{*}{ TRN } & \multirow[b]{2}{*}{ Classification } \\
\hline & & Cultivar & Botanical name & & & & \\
\hline 41 & Andhra Pradesh, South India & Cadenera fine & Citrus sinensis 'Cadenera' & 'AP6' & KJ885187 & 5 & Class I \\
\hline 42 & Andhra Pradesh, South India & Madam venus & Citrus sinensis & 'AP9' & KJ885188 & 5 & Class I \\
\hline 43 & Andhra Pradesh, South India & Dancy Tangerine & Citrus tangerine & 'AP2' & KJ885189 & 5 & Class I \\
\hline 44 & Andhra Pradesh, South India & Sour orange & Citrus aurantium & 'AP7' & KJ885190 & 5 & Class I \\
\hline 45 & Karnataka, South India & Pummelo & Citrus grandis & 'CH-R1' & KJ885219 & 11 & Class III \\
\hline 46 & Karnataka, South India & Sour orange & Citrus aurantium & 'CH-S3' & KJ885220 & 3 & Class I \\
\hline 47 & Karnataka, South India & Grapefruit & Citrus paradise & 'CH-G4' & KJ885221 & 10 & Class II \\
\hline 48 & Karnataka, South India & Coorg mandarin & Citrus reticulate & 'CH-CR5' & KJ885222 & 5 & Class I \\
\hline 49 & Karnataka, South India & Coorg mandarin & Citrus reticulate & 'CH-U6’' & KJ885223 & 6 & Class II \\
\hline 50 & West Bengal, Eastern India & Pummelo & Citrus grandis & 'Kal-3’' & KJ921625 & 7 & Class II \\
\hline 51 & West Bengal, Eastern India & Khasi mandarin & Citrus reticulata & 'Kal-4’ & KJ921626 & 6 & Class II \\
\hline 52 & West Bengal, Eastern India & Khasi mandarin & Citrus reticulata & 'Kal-5' & KJ921627 & 5 & Class I \\
\hline 53 & West Bengal, Eastern India & Khasi mandarin & Citrus reticulata & 'Kal-10a' & KJ921628 & 4 & Class I \\
\hline 54 & West Bengal, Eastern India & Khasi mandarin & Citrus reticulata & 'Kal-10b' & KJ921629 & 4 & Class I \\
\hline 55 & West Bengal, Eastern India & Khasi mandarin & Citrus reticulata & 'Kal-12a' & KJ921630 & 5 & Class I \\
\hline 56 & West Bengal, Eastern India & Khasi mandarin & Citrus reticulata & 'Kal-12b' & KJ921631 & 8 & Class II \\
\hline 57 & Assam, Northeast India & Khasi mandarin & Citrus reticulata & 'KhM-ii' & KJ885191 & 7 & Class II \\
\hline 58 & Assam, Northeast India & Khasi mandarin & Citrus reticulata & 'KhM-iii' & KJ885192 & 7 & Class II \\
\hline 59 & Assam, Northeast India & Mosambi, sweet orange & Citrus sinensis & 'Mo-i' & KJ885193 & 8 & Class II \\
\hline 60 & Assam, Northeast India & Assam lemon & Citrus limon L. Burmf & 'AsL-i' & KJ885194 & 7 & Class II \\
\hline 61 & Assam, Northeast India & Khasi mandarin & Citrus reticulata & 'KhM-i’' & KJ885195 & 9 & Class II \\
\hline 62 & Assam, Northeast India & Khasi mandarin & Citrus reticulata & 'KhM-vii' & KJ885196 & 6 & Class II \\
\hline 63 & Assam, Northeast India & Khasi mandarin & Citrus reticulata & 'KhM-vi' & KJ885197 & 7 & Class II \\
\hline 64 & Assam, Northeast India & Khasi mandarin & Citrus reticulata & 'AK2-KhM' & KJ885198 & 8 & Class II \\
\hline 65 & Assam, Northeast India & Khasi mandarin & Citrus reticulata & 'AK3-KhM' & KJ885199 & 8 & Class II \\
\hline 66 & Assam, Northeast India & Khasi mandarin & Citrus reticulata & 'AK4-KhM' & KJ885200 & 7 & Class II \\
\hline 67 & Assam, Northeast India & Khasi mandarin & Citrus reticulata & 'AK5-KhM' & KJ885201 & 7 & Class II \\
\hline 68 & Assam, Northeast India & Khasi mandarin & Citrus reticulata & 'AK7-KhM' & KJ885202 & 7 & Class II \\
\hline 69 & Assam, Northeast India & Khasi mandarin & Citrus reticulata & 'AK8-KhM' & KJ885203 & 7 & Class II \\
\hline 70 & Assam, Northeast India & Mosambi, sweet orange & Citrus sinensis & 'AK9-Mo' & KJ885204 & 7 & Class II \\
\hline 71 & Assam, Northeast India & Mosambi, sweet orange & Citrus sinensis & 'AK10-Mo' & KJ885205 & 7 & Class II \\
\hline 72 & Assam, Northeast India & Mosambi, sweet orange & Citrus sinensis & 'AK11-Mo’' & KJ885206 & 13 & Class III \\
\hline 73 & Assam, Northeast India & Mosambi, sweet orange & Citrus sinensis & 'AK12-Mo' & KJ885207 & 7 & Class II \\
\hline 74 & Assam, Northeast India & Mosambi, sweet orange & Citrus sinensis & 'AK13-Mo' & KJ885208 & 6 & Class II \\
\hline 75 & Mizoram, Northeast India & Khasi mandarin & Citrus reticulata & 'M-5' & KJ885227 & 7 & Class II \\
\hline 76 & Mizoram, Northeast India & Assam lemon & Citrus limon L. Burmf & 'M-2' & KJ885228 & 4 & Class I \\
\hline 77 & Mizoram, Northeast India & Pummelo & Citrus grandis & 'M-4' & KJ885229 & 8 & Class II \\
\hline 78 & Sikkim, Northeast India & Sikkim mandarin & Citrus reticulata & 'SK-6’' & KJ885240 & 6 & Class II \\
\hline 79 & Sikkim, Northeast India & Sikkim mandarin & Citrus reticulata & 'SK-13' & KJ885241 & 13 & Class III \\
\hline 80 & Sikkim, Northeast India & Sikkim mandarin & Citrus reticulata & 'SK-14' & KJ885242 & 5 & Class I \\
\hline 81 & Sikkim, Northeast India & Sikkim mandarin & Citrus reticulata & 'SK-16' & KJ885243 & 5 & Class I \\
\hline
\end{tabular}


Although the primary reason for TRN copy number variation among the ' $\mathrm{Ca}$. L. asiaticus' isolates is unknown, it is widely believed that it provides the selective advantages to the bacteria adapting to newer set of environmental conditions such as host species, soil, and temperature variations $(25,26)$. Both biotic and abiotic factors are known to play a significant role in affecting the repeat number instability; examples include $\mathrm{CT}$ repeat contraction upon fungal infection (29) and repeats in bacteria that undergo frequent adaptive, environmentally stimulated mutations (28). In the present study, we noticed that isolates with a similar TRN copy numbers were not favored by any particular citrus cultivar. However, the higher TRN copy numbers (TRN $>10$ but $\leq 15)$ were only found among widely grown citrus cultivars, mandarin, sweet orange, and acid lime. We also noticed that ' $\mathrm{Ca}$. L. asiaticus'

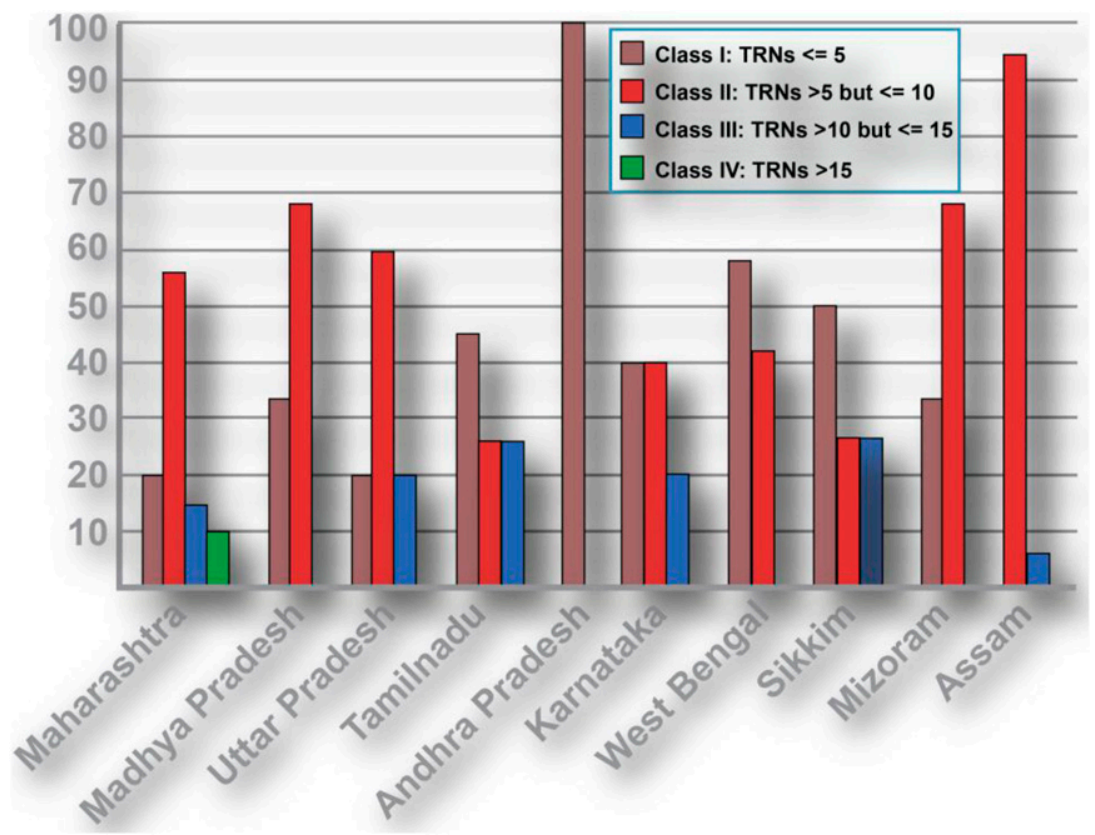

Fig. 3. Percent distribution of 'Candidatus Liberibacter asiaticus' isolates collected from different states of India that were surveyed during this study. The class II isolate is predominantly higher in all states followed by class I and then class III isolates. The class IV isolate is localized and found only in the Maharashtra state, which has the greatest area coverage under citrus crops in India.

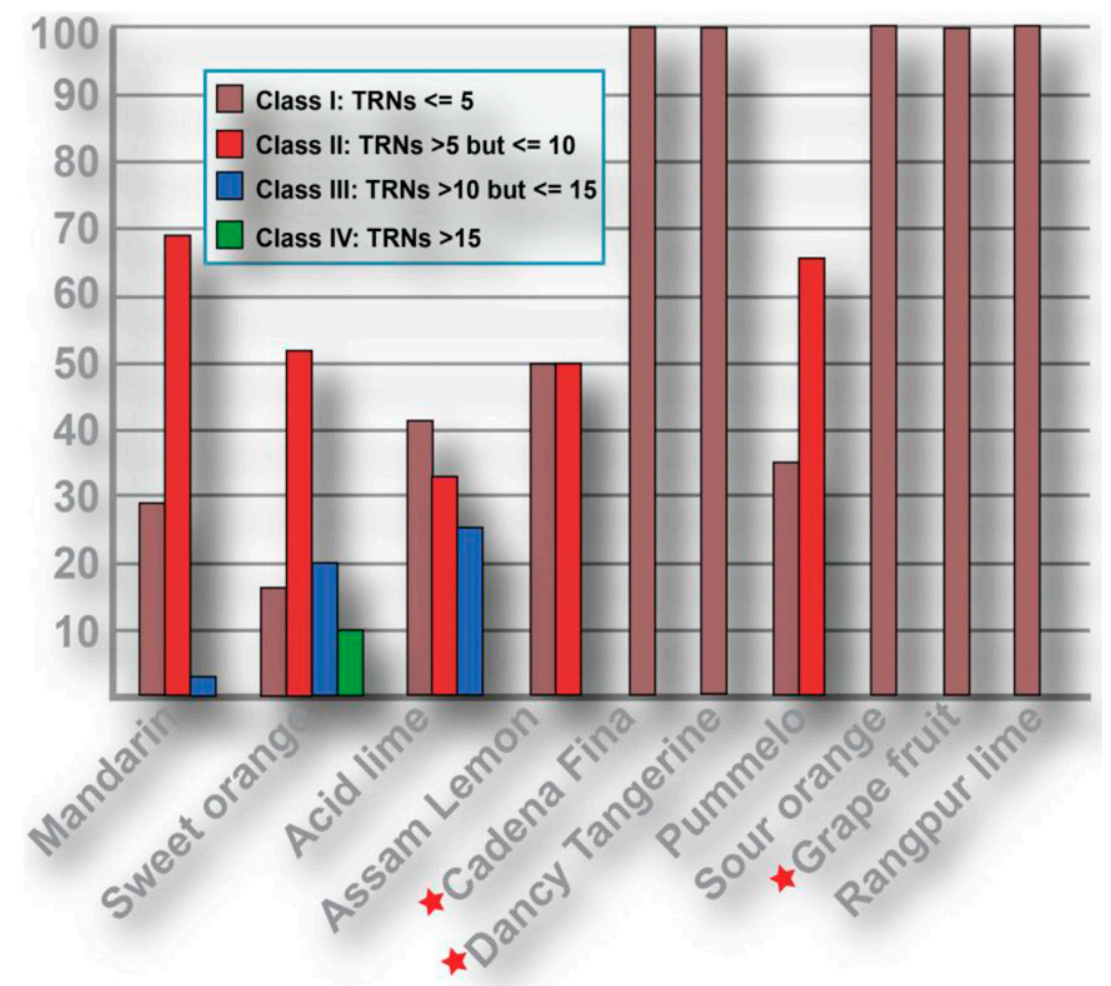

Fig. 4. Percent distribution of Indian 'Candidatus Liberibacter asiaticus' types in various citrus cultivars. Note that the most important commercial cultivars grown in India are mandarin, sweet orange, and acid lime and also the only cultivars that support all three ' $\mathrm{Ca}$. L. asiaticus' strains. The star indicates that a single sample was analyzed in this study under these cultivars. 
genotypes with highest TRN (>15) only found in the state of Maharashtra in sweet orange might suggest adaptive selection of the pathogen. Similar incidences of high TRN copy numbers in ' $\mathrm{Ca}$. L. asiaticus' isolates were localized to the central part of Florida (6), although pathogen adaptability was not suggested.

In the northeastern states of India, ' $\mathrm{Ca}$. L. asiaticus' genotypes TRN6 and TRN7 were predominant $(53.12 \%)$ and this area is geographically closer to Guangdong region of China where predominant presence of TRN6 and TRN7 genotypes were observed (6). This region, with its long history of citrus cultivation and believed as the center of citrus origin, perhaps lead to the localized stabilization of genotypes having similar TRNs.

In summary, analysis of the TRNs in the CLIBASIA_01645 locus of ' $\mathrm{Ca}$. L. asiaticus' associated with the HLB of citrus suggests that India represents a much more diversified set of ' $\mathrm{Ca}$. L. asiaticus' populations than previously reported for south China and Florida. The CLIBASIA_01645 locus of the ' $\mathrm{Ca}$. L. asiaticus' was found to be useful to detect and characterize the genomic variability of the bacterial population. This study represents the first attempt to document variations of Indian ' $\mathrm{Ca}$. L. asiaticus' strains and potentially would help in understanding the variabilities of global ' $C a$. L. asiaticus' populations.

\section{ACKNOWLEDGMENTS}

We thank T. Schafer, The Whitney Laboratory for Marine Bioscience, University of Florida, for critically reviewing the manuscript and D. K. Agrawal, Principal Scientist, ICAR-DSR, and U. Pradesh for performing statistical analysis.

\section{LITERATURE CITED}

1. Ahlawat, Y. S. 1997. Virus, greening bacterium and viroids associated with citrus (Citrus spp.) decline in India. Indian J. Agric. Sci. 67:51-57.

2. Bastianel, C., Garnier-Semancik, M., Renaudin, J., Bové, J. M., and Eveillard, S. 2005. Diversity of 'Candidatus Liberibacter asiaticus,' based on the omp gene sequence. Appl. Environ. Microbiol. 71:6473-6478.

3. Bove, J. M. 2006. Huanglongbing: A destructive, newly-emerging, centuryold disease of citrus. J. Plant Pathol. 88:7-37.

4. Capoor, S. P. 1963. Decline of citrus trees in India. Bull. Natl. Inst. Sci. India 24:48-64.

5. Capoor, S. P., Rao, D. G., and Viswanath, S. M. 1967. Diaphorina citri Kuwayama, a vector of the greening disease of citrus in India. Indian J. Agric. Sci. 37:572-576.

6. Chen, J., Deng, X., Sun, X., Jones, D., Irey, M., and Civerolo, E. 2010. Guangdong and Florida populations of 'Candidatus Liberibacter asiaticus' distinguished by a genomic locus with short tandem repeats. Phytopathology 100:567-572.

7. Coletta-Filho, D. H., Takita, M. A., de Souza, A. A., Aguilar-Vildoso, C. I., and Machado, M. A. 2001. Differentiation of strains of Xylella fastidiosa by a variable number of tandem repeat analysis. Appl. Environ. Microbiol. 67:4091-4095.

8. da Graça, J. V. 2010. Etiology, history and world situation of citrus Huanglongbing. 2nd International workshop on citrus Huanglongbing and the Asian citrus psyllid. Mérida, Yucatán, México.

9. Deng, X., Chen, J., Feng, Z., Shan, Z., Guo, H., Zhu, J., Li, H., and Civerolo, E. L. 2008. Identification and characterization of the Huanglongbing bacterium in pummelo from multiple locations in Guangdong, P.R. China. Plant Dis. 92:513-518.

10. Deng, X., Chen, J., and Li, H. 2008. Sequestering from host and characterization of sequence of a ribosomal RNA operon ( $r r n$ ) from 'Candidatus Liberibacter asiaticus'. Mol. Cell. Probes 22:338-340.

11. Deng, X., Lopes, S., Wang, X., Sun, X., Jones, D., Irey, M., Civerolo, E., and Chen, J. 2014. Characterization of 'Candidatus Liberibacter asiaticus' populations by double-locus analyses. Curr. Microbiol. 69:554-560.

12. Duan, Y., Zhou, L., Hall, D. G., Li, W., Doddapaneni, H., Lin, H., Liu, L., Vahling, C. M., Gabriel, D. W., Williams, K. P., Dickerman, A., Sun, Y., and Gottwald, T. 2009. Complete genome sequence of citrus Huanglongbing bacterium, 'Candidatus Liberibacter asiaticus' obtained through metagenomics. Mol. Plant-Microbe Interact. 22:1011-1020.
13. Fraser, L. R., Singh, D., Capoor, S. P., and Nariani, T. K. 1966. Greening virus, the likely cause of citrus dieback in India. FAO Plant Prot. Bull. 14: 127-130.

14. Garnier, M., Jagoueix-Eveillard, S., Cronje, P. R., Le Roux, H. F., and Bove, J. M. 2000. Genomic characterization of a Liberibacter present in an ornamental rutaceous tree, Calodendrum capense, in the Western Cape Province of South Africa. Proposal of 'Candidatus Liberibacter africanus subsp. capensis'. Int. J. Evol. Microbiol. 50:2119-2125.

15. Ghosh, D. K., Bhose, S., Mukherjee, K., and Baranwal, V. K. 2013. Sequence and evolutionary analysis of ribosomal DNA from Huanglongbing (HLB) isolates of western India. Phytoparasitica 41:295-305.

16. Gomez, K. A., and Gomez, A. A. 1984. Page 680 in: Statistical Procedures for Agricultural Research. John Wiley and Sons, New York.

17. Halbert, S. E. 2005. The discovery of Huanglongbing in Florida. Proc. 2nd Int. Citrus Canker and Huanglongbing Res. Work., Florida Citrus Mutual, Orlando.

18. Halbert, S. E., and Manjunath, K. L. 2004. Asian citrus psyllids (Sternorryncha:Psyllidae) and greening disease of citrus: A literature review and assessment of risk in Florida. Fla. Entomol. 87:330-353.

19. Henderson, S. T., and Petes, T. D. 1992. Instability of simple sequence DNA in Saccharomyces cerevisiae. Mol. Cell. Biol. 12:2749-2757.

20. Islam, M., Glynn, J. M., Bai, Y., Coletta-Filho, H. D., Gopal, K., Civerola, E. L., and Lin, H. 2012. Multilocus microsatellite analysis of 'Candidatus Liberibacter asiaticus' associated with citrus Huanglongbing worldwide. BMC Microbiol. 12:39.

21. Jagoueix, S., Bove, J. M., and Garnier, M. 1996. PCR detection of the two 'Candidatus Liberibacter species associated with greening disease of citrus. Mol. Cell. Probes 10:43-50.

22. Jagoueix, S., Bove, J. M., and Garnier, M. 1997. Comparison of the 16S/23S ribosomal intergenic regions of "Candidatus Liberibacter asiaticum" and "Candidatus Liberibacter africanum," the two species associated with citrus huanglongbing (greening) disease. Int. J. Syst. Bacteriol. 47:224-227.

23. Katoh, H., Subandiyah, S., Tomimura, K., Okuda, M., Su, H.-J., and Iwanami, T. 2011. Differentiation of "Candidatus Liberibacter asiaticus" isolates by variable-number tandem-repeat analysis. Appl. Environ. Microbiol. 77:1910-1917.

24. Lin, K. H. 1956. Observations on yellow shoot of citrus. Acta Phytopathol. Sin. 2:1-11.

25. Liu, R., Zhang, P., Pu, X., Xing, X., Chen, J., and Deng, X. 2011. Analysis of a prophage gene frequency revealed population variation of Candidatus Liberibacter asiaticus from two citrus-growing provinces in China. Plant Dis. 95:431-435.

26. Ma, W., Wen, X., Gu, X., Deng, X., and Chen, J. 2014. Population structure of 'Candidatus Liberibacter asiaticus' in southern China. Phytopathology 104:158-162.

27. Raychaudhuri, S. P., Nariani, T. K., and Ahlawat, Y. S. 1977. Dieback of citrus in India. Proc. Int. Soc. Citriculture 3:914-918.

28. Rosenberg, S. M. 2001. Evolving responsively: Adaptive mutation. Nat. Rev. Genet. 2:504-515.

29. Schmidt, A. L., and Mitter, V. 2004. Microsatellite mutation directed by an external stimulus. Mutat. Res. Fundam. Mol. Mech. Mutagen 568: 233-243.

30. Shen, Z., Feng, Z., Zhou, G., and Deng, X. 2008. 16S rDNA cloning and sequence analysis of citrus huanglongbin bacterial strains from five provinces in southern China. J. South China Agric. Univ. 29:25-29.

31. Strand, M., Prolla, T. A., Liskay, R. M., and Petes, T. D. 1993. Destabilization of tracts of simple repetitive DNA in yeast by mutations affecting DNA mismatch repair. Nature 365:274-276.

32. Teixeira, D. C., Saillard, C., Eveillard, S., Danet, J. L., da Costa, P. I., Ayres, A. J., and Bove, J. M. 2005. 'Candidatus Liberibacter americanus', associated with citrus huanglongbing (greening disease) in São Paulo State, Brazil. Int. J. Syst. Evol. Microbiol. 55:1857-1862.

33. Tomimura, K., Miyata, S., Furuya, N., Kubota, K., Okuda, M., Subandiyah, S., Hung, T., Su, H., and Iwanami, T. 2009. Evaluation of genetic diversity among 'Candidatus Liberibacter asiaticus' isolates collected in Southeast Asia. Phytopathology 99:1062-1069.

34. van Belkum, A., Scherer, S., van Alphen, L., and Verbrugh, H. 1998. Short sequence DNA repeats in prokaryotic genomes. Microbiol. Mol. Biol. Rev. 62:275-293.

35. Wang, X., Zhou, C., Deng, X., Su, H., and Chen, J. 2012. Molecular characterization of a mosaic locus in the genome of 'Candidatus Liberibacter asiaticus'. BMC Microbiol. 12:18.

36. Zhao, X. Y. 1981. Citrus yellow shoot (Huanglongbing) in China: A review. Proc. Int. Soc. Citricult. 1:466-469. 